\title{
IN SUPPORT OF A 'LIVING WAGE': RESEARCH ON INTERNATIONAL AND DANISH TRENDS AND ISSUES OF 'WORKING POOR'.
}

\author{
Erling Rasmussen \\ Department of Management, AUT Business \\ School, Auckland University of Technology \\ Jens Lind \\ Department of Sociology and Social Work, \\ University of Aalborg, Denmark
}

\begin{abstract}
In May 2012, a campaign started in support of a New Zealand 'living wage'. This happened in light of many New Zealand workers receiving wages at or just above the statutory minimum wage and that several fast-growing sectors continue to establish many low paid jobs. While the paper's starting point is the New Zealand 'living wage' debate, the issues discussed have been part of international debates about the existence and consequences of low paid work. These debates have highlighted that some countries have been better at containing low paid work. On this background, this paper focuses on the trends and issues surrounding 'working poor' in Denmark. As detailed, the Danish labour market has succeeded in having a relatively low level of 'working poor'. This has even happened in several service sector industries renowned for their propensity to create low paying jobs. However, the paper also questions the stability of the so-called Danish Model based on an open labour market with large in-and outflows of migrants and with a reliance on collective bargaining/agreements, with limit state regulation and, in particular, no statutory minimum wage. $^{i}$
\end{abstract}

\section{Introduction}

In May 2012, a campaign started in support of a New Zealand 'living wage'. Initiated by the Service and Food Workers Union Nga Ringa Tota (SFWU), Living Wage Aotearoa NZ has grown into a broadly based community and union campaign with over 100 organisations endorsing a call for a living wage in New Zealand in late 2012. The campaign is partly a response to the growing concerns about low wages in New Zealand where many workers and families are struggling financially and it partly builds on similar campaigns in other AngloAmerican countries (USA, UK, Ireland). There are particular New Zealand factors at play as the country seeks to counter the fall-out from the Global Financial Crisis, high youth unemployment, and an exodus of skilled workers to overseas labour markets. In particular, the limited growth in statutory minimum wages has had a negative impact as have the Government's reduction in employee entitlements and its emphasis on work - even very low paid work - being a way to deal with employment and welfare issues.

However, the wider international concerns about unemployment, low wages and employee rights indicate that strong underlying structural and political issues associated with the type of work and labour markets being created. It is well-known from several OECD countries that the recent growth in low paying jobs has been associated with job growth in low wage service sector employment in areas such as hospitality, cleaning, age care and retail. It has also coincided with a decline in union membership and collective bargaining, a rise in atypical employment patterns and a stronger employer/management focus on costs and labour market flexibility. Still, the debates about the trends and consequences of low wage work have highlighted that some countries have a much better record in containing or reducing low wage work. In this paper, we draw on the research supported by the Sloan Foundation which has found a wide range of incidences of 'working poor'.

With the growth in low wage service sector employment and changes in employment relations and employment patterns, there seems to be no stopping the incidence of 'working poor' rising. While low wage employment can be contained through legislative and collective bargaining interventions - which is really what the living wage campaign is about - this has been met with fierce employer and political resistance in many OECD countries. Social welfare interventions to mitigate the 
income deficiencies are faced with the post-2008 pressure on public budgets. New Zealand changes to statutory minima, welfare reforms and public sector cuts fit well with that picture. This raises the question: what can and should be done about low wage work?

This rather simple question is sometimes answered by: "nothing". This has been, for example, the position of the now defunct Business Roundtable, it was part of Thatcher's attack on minimum wage councils in the UK, and it created a lot of discussion amongst American public policy analysts and economists in the 1980s. It is common amongst economists to point to unemployment consequences of a certain minimum wage level or unemployment rises of increases in minimum wages. Low wages can also be seen as a competitive advantage, as witnessed in April 2012 comments from Finance Minister Bill English. In the "nothing" camp, the solutions to 'working poor' are normally higher productivity, investment in education and training, more labour market flexibility, and exporting low wage jobs to countries with lower wages. These solutions tend to have fairly broad political support (as discussed in more detail below) but they tend to take considerable time and may not work sufficiently. Thus, in many countries low wage work is seen as a more immediate problem and 'fairness' and wider social consequences have tended to prompt some interventions over time. While the income and longer term social mobility issues can partly be dealt with through various tax and social welfare measures, there appear to be only two effective counter-measures to low wage work: statutory minimum wages and/or collectively agreed minimum wages.

While low wage work has been become a concern in many OECD countries the recent growth in 'working poor' is not inevitable and is not a common phenomenon in all OECD countries. The wide range of incidences of 'working poor' in the relatively few OECD countries investigated by research funded by the Sloan Foundation is just one indication of how countries deal differently with low wage work. Although this is a rather complex issue we will highlight some of the areas which present a more positive picture of possible reactions. In particular, we will focus on Danish trends in the major sections of this paper since Denmark has had a very low incidence of 'working poor' and the so-called Danish Model has been regarded a rather successful in recent years. While one section will highlight some of the approaches which have succeeded in containing low wage work in Denmark we will in the last section overview some of the 'danger signals’ which may derail the Danish Model and lead to a rise in 'working poor'.

\section{International research on 'working poor' and the 'Danish Model' of employment relations}

In recent years, the so-called 'Danish Model' and in particular its promotion of 'flexicurity' has attracted substantial overseas interest (Andersen \& Svarer, 2007; Due et al., 1994). While the emphasis on a flexible labour market and social welfare security has been a key driver of the Danish Model's notoriety, it has also been used in promoting a 'Third Way' or Social Democracy approach to economic, social and labour market policies, being used as a positive example in the move towards the highskill, high-wage economy, and an inclusive labour market. It has also been highlighted by the Sloan Foundation in its comprehensive comparative analysis of ‘working poor' or low-wage work:

Here are the basic facts. In 2005, the incidence of lowwage work was 25 percent in the United States, 22.1 percent in the United Kingdom, 20.8 percent in Germany (2004), 18.2 percent in the Netherlands (2004), 12.7 percent in France (2002) and 8.5 percent in Denmark. (Solow, 2008: 6).

These are considerable differences and the percentage figures are influenced by the definition of low-wage work. The Sloan Foundation research has used the standard European definition where low-wage workers or 'working poor' is defined as "anyone who earns less than two-thirds of the national median wage” (Solow, 2008: 5). Thus, the number of 'working poor' will be influenced by the dispersion of the wage distribution, particularly the compression of the wage distribution for low-wage work. Besides the low incidence of low-wage work, there are two other key characteristics which influence the experience of low-wage workers. First, there is considerable mobility out of low-wage work: “...of every one hundred Danes who were low-wage workers in 1995, only about ten remained in that status five years later. If there is a chronically low-wage population, it appears to be quite small.” (Solow, 2008: 14). Second, there is also considerable support in terms of active labour market and social welfare measures. These are features which set the Danish approach apart from most other OECD countries and key features will be highlighted below. While it has provided some impressive employment results in recent years it has made the Danish approach very expensive: "Danish welfare policies are comprehensive, and state expenditures on labor market programs are high; as a result, Denmark spends more on these programs than any other country.” (Westergaard, 2008: 32).

The low incidence of low-wage work (the compression of wage distribution) as well as the comprehensive labour market and social welfare measures bring the much debated rise of inequality into the picture (Andersen et al., 2012). ${ }^{1}$ This is clearly a complex issue which, in respect of Danish Model, is further debated below. How lowwage work is treated in particular countries, industries and firms is of major research significance and the Sloan Foundation research has opened for further investigation thereof.

${ }^{1}$ Even the OECD - often a key supporter of more 'market' and 'deregulation' - has recently voiced concern over the rise in inequality (Politiken, 2012) as has The Economist (2012). While the extent and actual impact across economies are debated, there are clearly concerns that growing inequality can bring about economic and social inefficiencies. 
One interesting hypothesis that emerged from this work was the notion that employers have significant discretion about the way they organize their used of low-skilled workers and the value they put on the continuity and productivity of their work force. The extreme versions came to be labelled "low-road" and "high-road" modes of organization. /.... Of course, the nature of technology and the competitive intensity in the industry are important determinants of labormarket outcomes. That is not in doubt. In some situations, however, there may be scope for several levels of wages and job quality for unskilled workers. /.... It then becomes important to the researcher to understand the broad factors that govern the typical choices made by employers. (Solow, 2008: 3).

While it is unclear to us how much discretion individual employers within particular countries and industries actually have, ${ }^{2}$ the quote does highlight that there appears to be systematic differences even when industry location and organisational size are adjusted for. As such, the Sloan Foundation research fits with other comparative employment relations theories and/or models which have tended to place Anglo-American countries in a different category from Denmark. One can point to neo-corporatist analyses of the 1980s (Schmitter, 1981; Crouch, 1985), the so-called Calmfors-Driffill hypothesis of the late 1980s (Calmfors \& Driffill, 1998), the Strategic Choice Model of the 1980s and 1990s (Katz \& Darbishire, 2000; Regini et al., 1999), the Variety of Capitalism of the 1990s and 2000s (Bamber et al., 2011). All of these theories and models put a lot of emphasis on institutional factors and they often place labour market and employment relations processes and outcomes at the centre of their discussions.

While Denmark and New Zealand is often not covered in mainstream comparative research it is obvious that they have had very different historical developments and they have followed rather different public policy paths over the last two to three decades. Radical changes have been the hallmark of the 'New Zealand experiment' where socalled 'Rogernomics' started a fundamental economic and social transformation which 'opened' the New Zealand economy and implemented adjustments across most public policy areas (Kelsey 1997). In particular, the public sector and labour market reforms have gained international notoriety (Boston et al., 1996; Dannin, 1997). The welfare support to and prevention of lowwage work became more evident under the Clark Labourled governments, where major increases in statutory minimum wages, enhanced employee rights, social welfare changes and housing subsidies shifted the goal

\footnotetext{
${ }^{2}$ We have already been involved in some research of the role and attitudes of New Zealand employers (Foster et al., 2011). As there has been very limited research of employer attitudes and their wide employment relations role, we are currently developing more comparative research, including a New Zealand-Danish comparison.
}

posts for 'working poor'. However, there has been a move towards a more neo-liberal, punitive approach in the post2008 period. Currently, it appears that employment - even low paid employment - is seen as a key public policy and public policy changes (for example, taxation, social welfare, employment minima) have done preciously little to limit inequality; rather the contrary.

Although Denmark has implemented considerable changes to its economic and social structures the changes have been done in a less abrupt manner. This has meant, as pointed out below, that there is now systematic DanishNew Zealand differences across a range of public policy areas and with considerable variation in key economic, social and labour market indicators. The limited rise of 'working poor' as a proportion of the workforce in Denmark has clearly been influenced by these changes and this is probably also the reason why Denmark despite the considerable international debate of inequality - has yet to experience a strong research and media focus on low-wage work. While the discussion above has shown how Denmark has had a low incidence of lowwage work and has also had high mobility out of low wage work it hasn't really said much about how this situation has come about and whether it can be sustained. These questions are dealt with in the next two sections.

\section{How has Denmark limited a rise of 'working poor' as a proportion of the workforce?}

Since the 1950s, Denmark has developed an economy, a social welfare system and an inclusive labour market which have been admired by overseas commentators. In the process, it has transformed itself from a relatively low wage country to a high-wage, high-skill, internationally integrated economy. There are many reasons for this development and has not always resulted in positive outcomes. Denmark has had its fair share of international pressures, economic downturns, public policy 'soulsearching, and some adverse economic and social changes. Thus, any brief explanation for this success will be superficial and, in the following, we will highlight only a few reasons and in particular those that can be used to compare and contrast New Zealand issues and trends.

The transformation towards high-wage, high-skill economy was part of the social democracy economic and social approach which promoted a strong economy and high productivity through an emphasis on education and upskilling, workplace democracy (employee 'voice' and influence) and equality and equity. The post-1950s economic upswing was characterised by investments in education, public sector activities (including kindergartens as women joined the labour market) and localised active labour market programmes. Similar public policy approaches could be found in other European countries and in New Zealand but there was a unique Danish approach which gave rise to the notion of the 'Danish Model' of employment relations. It was a strongly solidaric approach which was build around the traditional self-determination of employers and unions and emphasised the role of 'solidaric wage bargaining' and income compression. Thus, while the state was active 
in developing welfare measures (including income redistribution through taxes and transfer payments), education and training programmes, and massive infrastructure projects there was limited intervention in the labour market or enhancing public sector ownership. Labour market regulation was mainly built on collective agreements and to a very limited degree on state intervention (which was normally prompted by joint employer-union suggestions). Compared to employment relations in New Zealand, the lack of legislative underpinnings is remarkable.

Besides this 'voluntarist nature' of Danish model, it is important to consider the importance of comprehensive state intervention.

"The Danish "flexicurity" model has achieved outstanding labour-market performance. The model is best characterised by a triangle. It combines flexible hiring and firing with a generous social safety net and an extensive system of activation policies. The Danish model has resulted in low (long-term) unemployment rates and the high job flows have led to high perceived job security." (Andersen et al., 2011: 1).

The comprehensive role of the social safety net means that most low paid employees will seldom suffer a drastic income reduction in the short term and many important employment entitlements are only partly dependent on having continuous employment. This creates a highly mobile workforce and many Danish workers will change jobs and experience short periods of unemployment. In that sense, labour market mobility is similar to the US trends where an economic down- or upturn prompts an immediate employment reaction. The average unemployment duration in Denmark tends to be less than 4 months and while this has drifted upwards following the Global Financial Crises, average unemployment duration is still low: "Still, workers that lost jobs in the midst of the recession found employment rather soon: 60\% after 13 weeks and $80 \%$ after 26 weeks.” (Andersen et al., 2011: 3). While the ceiling on unemployment benefit payments provides a financial incentive to rejoin employment for higher paid workers, the activation measures are very important for low paid workers and there is a considerable degree of compulsion (financial punishment) to be actively involved in these measures.

As neo-liberal thinking permeated public policy approach in many OECD countries in the new millennium, the Danish/Scandinavian approach stayed remarkably different and successful: "Despite high taxes, high unionization rates, and egalitarian income distribution they demonstrated from the mid-1990s to 2008 that it was possible to improve competitiveness, secure macroeconomic balances, lower unemployment, and engage a high proportion of women, youngsters, and senior people in economic activity, while state institutions played a large role in the economy" (Kristensen \& Lilja, 2011: vii). In fact, the Danish trends show several trends opposite to neo-liberal thinking becoming more embedded in the post-1980 period: union density topped in the mid 1990s, the public sector was still expanding post 2000, and high income tax rates (for most employees) and significant public transfers are still in place. Thus, even with the various current 'pressures' on the Danish approach highlighted below, this is still a paradoxical model for many outsiders as it is so different and yet successful with the 'wrong' public policy approach.

As described, the incidence of low-wage work is partly influenced by the 'Danish Model' and its 'flexicurity' approach but is also partly influenced by common understandings build over a long time amongst the key decision-makers. In particular, there appears to be a common state-employer-union understanding that continuous adaptation (to adjust in light of prevailing economic and social issues) and a focus on productivity is necessary and this understanding influences national collective bargaining as well as at organisational level. Productivity measures are often implemented at workplace levels where shop stewards and works councils can have considerable influence, and employees' positive contributions are therefore important in generating flexible and effective workplaces (Kristensen \& Lilja, 2011; Rasmussen, O’Neil \& Chalmers, 2006). The connection between high wage work and productivity can also be found in the unions' rather positive approach to outsourcing/offshoring of low wage work. While job protection is part of the unions' strategic approach it sees the containment of low wage work as an important part of its solidaric wage bargaining. It also appears that Danish employers are much more vigilant in 'policing' and advocating against low wage work where adherence to collectively agreed norms is taken quite serious.

There have always been areas where collective agreements do not cover work (Scheuer, 1996) and these areas are clearly problematic for unions as they can undermine minimum wage norms. As discussed below, there have started to be some serious doubts about containing areas outside the collective agreement coverage. Another issue is how to fit people with low skills, low engagement or with physical and/or mental constraints into workplaces which are driven by high labour costs and international competition. There have been some serious public policy debates about the many people who can't get a permanent position in the Danish labour market and the many people who have been 'retired' temporarily or often permanently from the labour market through various sickness and pension schemes (Velfærdskommissionen, 2004; Møller et al., 2008). Finally, this is a very expensive system which tends to put pressure on employers, employees and particularly state expenditures. The Danish high level of taxation - driven by high income taxes, local taxes and a $25 \%$ VAT rate often astounds foreign observers. While social welfare, health and education account for a large part of expenditure the active labour market measures and the wider context of extensive free education and training opportunities are very expensive to run.

However, as Kristensen and Lilja (2011) have illustrated, the rather large and expensive welfare state can positively support organisational adjustments and allow for 
continuous upskilling and learning. Under increasing international competition, organisations and individuals have to experiment with new business models, new working arrangements, and new career and living patterns. This demands high levels of flexibility and connectivity, especially of the many small-to-medium sized Danish firms. In this volatile labour market, individual workers have to rely on more than just traditional supports such as crèche and kindergarten facilities, paid parental leave, and protected jobs. In order to incorporate new family patterns and continuous upskilling requirements, new welfare and active labour market measures involve the development of individualised employment planning, transfer/job change supports, temporary leave schemes, individualised social services and so on.

\section{Can the Danish Model continue in a globalised/international labour market?}

Despite its remarkable success in the last couple of decades there are doubts whether the Danish Model is viable in a globalised labour market. As it is based largely on collectively agreed arrangements it demands a consensus approach and comprehensive coverage of collective agreements and arrangements. This cannot be taken for granted as discussed below. Interestingly, the other two aspects of 'flexicurity' - state support of incomes and active labour market interventions have only had minor adjustments in the millennium and, if anything, have been seen as more important to deal with a more fluently labour market and with demographic pressures. There have been some adjustments to deal with the costs associated with state interventions and there have been a tightening of unemployment and benefit regulations. This has meant that unemployed and beneficiaries have faced tougher times. It has yet to prompt a public debate about 'working poor' or about a living wage, despite the unions trying to engage young people and un-organised employees in a wider discussion about how to prevent low wage work. This public debate may still surface as there has been considerable media and political debate about the growing inequality in Denmark. Inequality is far from American proportions as the Gini coefficient has increased from 20.6 to 24.3 over the last 15 years (OECD
StatExtracts) as the economic upswing has benefited highly paid employees most.

Thus, the main doubts about the viability of the Danish Model are linked to collectively agreed arrangements. Danish research has pointed to three trends which could threaten the sustainability of the Danish Model (Due \& Madsen, 2008; Knudsen \& Lind, 2012):

- Decentralisation of collective bargaining

- Union density decline and less comprehensive collective bargaining

- European Union regulations and migrant labour

Over the last couple of decades, there has been a decentralisation of collective bargaining. This process often called “managed decentralisation" or "centralised decentralisation" - has made the key peak employer and union organisations (DA and LO) less important. Instead the industry organisations have gained in importance and are now the key parties concluding collective agreements. At the same time, collective agreements have become less prescriptive and many important employment conditions - including wages and working hours - are often negotiated at workplace level. This has clearly opened for more employer-driven flexibility but with strong union and employee influence on workplace decision-making it is a far cry from employer-driven flexibility in New Zealand. It has also yet to open for a strong growth in 'working poor' as, despite the growing importance of workplace wage negotiations, wage differentials have not increased considerably.

The Danish Model assumes that collectively agreed arrangements will cover the labour market in a nearly comprehensive fashion. This assumption has been questioned since the research by Scheuer (1996) and it is estimated currently that around $60 \%$ of the private sector workforce are covered by collective agreements. This clear leaves considerable room for un-organised employers and employees for developing low wage work. In other countries, there has been a strong decline in union density but this has not been the case in Denmark as can be seen from Table 1 below. 
Table 1: Members of trade unions in Denmark (in thousands)

\begin{tabular}{|c|c|c|c|c|c|c|c|}
\hline & 1985 & 1995 & 2000 & 2005 & 2009 & 2010 & 2011 \\
\hline Workforce* & 2.434 & 2.547 & 2.614 & 2.640 & 2.677 & 2.676 & 2.655 \\
\hline LO & 1.119 & 1.208 & 1.167 & 1.142 & 987 & 955 & 917 \\
\hline FTF & 309 & 332 & 350 & 361 & 358 & 358 & 356 \\
\hline AC & 74 & 132 & 150 & 163 & **133 & 137 & 139 \\
\hline $\begin{array}{l}\text { Outside the Peak } \\
\text { Organisations }\end{array}$ & 198 & 190 & 203 & 227 & $* * 340$ & 354 & 366 \\
\hline Union members & 1.700 & 1.809 & 1.802 & 1.799 & 1.665 & 1.631 & 1.603 \\
\hline Union density & 70 & 73 & 72 & 72 & 68 & 67 & 67 \\
\hline \multicolumn{8}{|c|}{ Members of Peak Organisations as percentage of all union members (\%) } \\
\hline LO & 66 & 65 & 62 & 60 & 54 & 53 & 52 \\
\hline FTF & 18 & 18 & 19 & 19 & 20 & 20 & 20 \\
\hline AC & 4 & 7 & 8 & 9 & 7 & 8 & 8 \\
\hline $\begin{array}{l}\text { Outside the Peak } \\
\text { Organisations }\end{array}$ & 12 & 10 & 11 & 12 & 19 & 19 & 20 \\
\hline
\end{tabular}

Source: LO 2011b

*Self-employed are not included

**These changes were prompted by that two member organisations ('Ingeniørforeningen' and 'Landinspektørforeningen') decided to leave AC.

LO is the traditional, mainly blue-collar, peak organisation, FTF mainly organises white-collar workers while AC have academically educated employees as members.

Table 1 indicates that there has been a relatively small drop in union density and there is still a very high level of union density compared to most other countries. However, there have been several important distributional changes. LO has lost some of its previous dominance as it has lost members. To a large degree, this has been driven by changes in the workforce composition as service sector and whitecollar jobs have grown. As the peak organisations often work together in securing the key employment conditions and arrangements this has had less impact on collective bargaining outcomes as could have been expected. The peak organisations are all advocating strong position on 'working poor' and they are often supported by peak employer associations as organised employers are trying to avoid being undercut by 'cheap labour' employers. However, the rise in union members outside the peak union organisations is rather more dangerous as this is partly built on the popularity of so-called 'discount unions'. These unions have normally rather weak or no collective agreements and this opens for low wage work. While there has been a strong growth in 'discount unions' over the last 6-7 years the full effect of this growth on low wage work is yet to manifest itself.

The European Union membership means that the Danish labour market has become part of the 'free mobility of capital and labour' within the EU countries. Workers from other EU countries can legally work in DK as employees in a Danish company or as employees in a foreign-owned company that operates in Denmark. In a Danish company, the non-Danish workers are subject to 
exactly the same rules and conditions as Danish workers are. In a foreign-owned company, the employment relationship is regulated by the Posted Worker Directive which is implemented via Danish legislation. According to this legislation, a foreignowned company must follow Danish legislation and agreements that regulate the working conditions of particular jobs. In both cases, there are clear prescriptions when legislation stipulates the regulations (such as safety at work, holidays, the legislation on white collar workers, equal treatment of men and women and equal pay, etc.). This is less clear-cut if the collective agreements do not stipulate wage levels, working time arrangements, and so on. These situations could easily open up for strong growth in 'working poor' as there are no statutory minima as a default option.

Finally, there have been several cases reported in the media where Danish and foreign-owned companies have ignored Danish legislative or collectively agreed regulations when employing non-Danish workers (for example, in the construction sector). In most of the reported cases as well as in the limited research done so far, migrant workers have been lower paid than Danish workers, they work longer hours, their working environment is sub-standard, and the work intensity is higher. (Hansen \& Hansen, 2009; Arnholtz \& Hansen, 2011; Pedersen \& Thomsen, 2011). This could become a considerable issue since there has been a strong growth recently of foreign workers in the Danish labour market; risen from 40,000 to 60,000 workers during 2008-11 despite rather low levels of economic activity.

\section{Conclusion}

The concerns about 'working poor' have grown in the new millennium as the wider impact of 'globalised' capitalism and labour markets has created considerable wage differentials and where large sections of the workforce are struggling financially in many OECD countries. The fall-out from the Global Financial Crisis has added further impetus. These concerns are also associated with other economic and social issues such as the wider impact of inequality, the ability to move out of low wage work, restricted education and upskilling opportunities and overall, the creation of a less inclusive society.

It is possible to contain low wage work and create a virtuous circle where a lower proportion of 'working poor' leads to positive economic and social dynamics. It also important to ensure that mobility out of low wage work is high. The low incidence and duration of low wage work are the key indicators which make the Danish Model and its 'flexicurity' and active labour market programmes stand out internationally. As shown, this is a particular approach which is based around factors, assumptions and norms which are seldom found in most other OECD countries. Thus, this paper is no attempt to make other countries copy the Danish Model but it can provide inspiration to rethink attitudes, preconceived ideas and existing structures of low wage work. Although the Danish Model has been and still is a rather successful approach one cannot take for granted that positive outcomes will continue. The Danish Model has already had to be adapted on a continuous basis in face of economic, social and employment problems and it is only part of a wider economic and social approach which has to deal with radical international market changes.

Finally, there are clear warnings signs that the Danish Model is struggling in face of changes to union membership, less collective bargaining coverage, and the integration of the Danish economy and labour market in the European Union 'free market' zone. The warning signs are directly linked to the ability of continuing the low incidence of low wage work and there are indications that low wage work has started to increase in construction and low paying service sector jobs. Overall, this makes us cautious about future trends and whether the Danish Model will, once again, be able to withstand external and internal pressures through adaption.

\section{References}

Andersen, L. Olsen, L., Ploug, N. \& Juul, J.S. (2012). Det danske klassesamfund, Gyldendal, København.

Andersen, T.M., Bosch, N., Deelen, A. \& Euwals, R. (2011). 'The Danish flexicurity model in the Great Recession.' VoxEU. www.voxeu.org/article [accessed 6 Nov 2012].

Andersen, T.M. \& Svarer, M. (2007). 'Flexicurity Labour Market Performance in Denmark.' CESifo Economic Studies, 53(3), 389-429.

Arnholtz, J., Hansen, N.W. (2011): Nye arbejdsmigranter på det danske arbejdsmarked, pp.109-132 In Larsen, T.P. (ed.): Insidere og outsidere, København, Jurist- og Økonomforbundets Forlag.

Bamber, G., Lansbury, R.D. \& Wailes, N. (eds.). (2011). International and Comparative Employment Relations. Globalisation and Change. $5^{\text {th }}$ Edition, Allen and Unwin, Sydney.

Begg, I. (2012) 'Is 'Flexicurity' Post-Crisis Europe's New Social Model?' Bloomberg News, 15 April 2012. [accessed 6 Nov 2012]

Boston, J., Martin, J., Pallot, J. \& Walsh, P. (1996). Public Management. Oxford University Press, Auckland. 
Calmfors, L. \& Driffill, J. (1998). 'Bargaining Structure, Corporatism and Macroeconomic Performance.' Economic Policy. 3, 13-61.

Crouch, C. (1985). 'Conditions for trade union wage restraint.' In Lindberg, L.N. \& Maier, C.S. (eds.). The Politics of Inflation and Economic Stagnation. Brookings Institute, Washington.

Dannin, E. (1997). Working Free: The origins and Impact of New Zealand's Employment Contracts Act. Auckland University Press, Auckland.

Due, J. \& Madsen, J.S. (2008). 'The Danish Model of Industrial Relations: Erosion or Renewal?' Journal of Industrial Relations, 50(3), 513-529.

Due, J., Madsen, J.S., Jensen, C.S. \& Petersen, L.K. (1994). The Survival of the Danish Model. DJØF Publishing, Copenhagen.

Economist. (2012). Special report: the world economy. The inequality debate. 13 October 2012.

Hansen, J.A., Hansen, N.W. (2009): Polonia i København, LO-dokumentation 1/2009, København, LO.

Katz, H. \& Darbishire, O. (2000). Converging Divergencies. Worldwide Changes in Employment Systems. ILR Press, New York.

Kelsey, J. (1997). The New Zealand experiment: A world model for structural adjustment? Auckland University Press, Auckland.

Knudsen, H., Lind, J. (2012). De danske modeller: Plus ca change, plus c'est la meme chôse?, Tidskrift for Arbejdsliv, 14( 2), 9-30.

Kristensen, P.H. \& Lilja, K. (eds.). (2011). Nordic Capitalisms and Globalisation. Oxford, Oxford University Press.

Lind, J. \& Rasmussen, E. (2008). 'Paradoxical patterns of part-time employment in Denmark?' Economic and Industrial Democracy. 29(4), 521-540.

Markey, R., Harris, C., Lind, J., Busck, O. \& Knudsen, H. (2010). 'The Effect of Employee Participation on Work Environment in Food Processing Industry in Denmark and New Zealand', Indian Journal of Industrial Relations, 45(4), 622-34.

McLaughlin, C. (2009). 'The ProductivityEnhancing Impacts of the Minimum Wage: Lessons from Denmark and New Zealand.' British Journal of Industrial Relations, 47(2), 327-348.

McLaughlin, C. (2010). 'Building a 'high road' economy? The Employment Relations Act in an international comparative perspective.' In
Rasmussen, E. (ed.), Employment Relationships. Workers, Unions and Employers in New Zealand. Auckland University Press, Auckland.Møller, I.H., Lind, J. \& Hansen, H. (2008). Aktivering - Disciplinering til arbejde. CASA, København.

Møller, I.H., Lind, J., Hansen, H. (2008). Aktivering - Disciplinering til arbejde. CASA, København.

Pedersen, L.M., Thomsen, T.M. (2011). 'Arbejdsmigration fra de nye EU-lande.' Tidsskrift for Arbejdsliv, 13( 3), 45-63.

Politiken. (2012). OECD advarer mod øget ulighed. 20 October 2012

Rasmussen, E. \& Lind, J. (2003). 'Productive employment relationships: European experiences.' New Zealand Journal of Industrial Relations, 28(2), 158-169.

Rasmussen, E. , O’Neil, P. \& Chalmers, P. (2006). International Experiences of Partnership. Department of Labour, Wellington.

Regini, M., Kitay, J. \& Baethge, M. (eds.). (1999). From Tellers to Sellers. MIT Press, Cambridge, MA.

Scheuer, S. (1996). Fælles aftale eller egen kontrakt $i$ arbejdslivet. Nyt fra Samfundsvidenskaberne, Copenhagen.

Solow, R. (2008). 'Introduction: The Danish Story.' In Westergaard-Nielsen, N. (ed.). Low-Wage Work in Denmark. Russell Sage Foundation, New York, pp. 1-15.

Velfærdskommissionen. (2004). Analyserapport Fremtidens velfard kommer ikke af sig selv. Velfærdskommissionen, København.

Westergaard-Nielsen, N. (2008). 'Low-Wage Work in Denmark.' In Westergaard-Nielsen, N. (ed.). Low-Wage Work in Denmark. Russell Sage Foundation, New York, pp. 16-31.

\footnotetext{
${ }^{\mathrm{i}}$ As we have researched New Zealand-Danish employment relations for many years, we can draw on several research projects (eg. Lind \& Rasmussen, 2008; Rasmussen \& Lind, 2003). However, this is also the start of a new research project and thus this paper needs to be further developed as it draws on a rich literature. The so-called Danish Model and 'flexicurity' has attracted a lot of research interest recently (eg. Andersen \& Svarer, 2007; Begg, 2012) as has the role of education and vocational training approaches in moving the Danish economy towards a flexible, "knowledge economy’ (eg. McLaughlin, 2009 \& 2010). Some interesting NZ-DK comparisons have also been done in the area of employee participation and well-being (see Markey et al., 2010).
} 